\title{
UJI EFEKTIVITAS SEDIAAN HAND SANITIZER KOMBINASI EKSTRAK DAUN KEMANGI (OCIMUM SANCTUM L) DAN EKSTRAK KULIT JERUK PURUT (Citrus hystrix)
}

\author{
Indri Kusuma Dewi, Bambang Yunianto \\ Kementerian Kesehatan Politeknik Kesehatan Surakarta Jurusan Jamu
}

\begin{abstract}
Absctract : Antiseptic Activity, Kemangi Leaf-Cytrus Hystrix Leather, Gel Antiseptic (Hand Sanitizer). It is known kemangi leaf had contained saponins, flavonoids and tannins that benefit as antibacterial, while in research by Susanti, 2010 had proven that leather of Citrus hystrix contained essential oil as antibacterial and used as antiseptic in pharmaceutical case. So, to get the optimal formula as hand sanitizer or antiseptic gels used combination two extracts kemangi leaf and Citrus hystrix leather. This research is an experimental research with Post Test Control Group Design to analyze antiseptic activity using the Replica methods with to account the number of colonies of microorganism. Statistic test to the number of colonies of microorganism with Anova Test one way that confidence level 95\% and obtained significance 0,000 the result $P<$ 0,05 and continued to Tukey HSD test that confidence level 95\%. The result statistic tes showed that have significan differences between negative control with the formula of gel antiseptic combination extract of kemangi leaf and extract Cytrus hystrix leather, so this formula have activity as antiseptic. The most effective variation concentration is concentration extract of kemangi leaf $75 \%$ and extract Cytrus hystrix leather $25 \%$.
\end{abstract}

Keywords : Antiseptic Activity, Kemangi Leaf- Cytrus Hystrix Leather, Gel Antiseptic (Hand Sanitizer)

Abstrak : Daya Antiseptik, Daun Kemangi-Kulit Jeruk Purut, Gel Antiseptik (Hand Sanitizer). Diketahui bahwa daun kemangi mempunyai kandungan senyawa saponin, flavonoid dan tanin yang bersifat sebagai antibakteri, sedangkan dalam penelitian Susanti,2010 terbukti bahwa kulit jeruk purut mengandung minyak atsiri yang mempunyai manfaat sebagai antibakteri dan dalam dunia farmasi digunakan sebagai pembersih. Oleh karena itu, untuk mendapatkan formula yang optimal sebagai hand sanitizer atau gel antiseptik digunakan kombinasi kedua ekstrak daun kemangi dan kulit jeruk purut. Penelitian ini merupakan penelitian eksperimental dengan Post Test Control Group Design untuk pengujian daya antiseptik menggunakan metode Replika dengan menghitung jumlah koloni mikroorganisme. Uji statistik dilakukan terhadap jumlah koloni mikroorganisme yang tumbuh dengan uji Anova one way dimana taraf kepercayaan 95\% diperoleh signifikansi 0,000 yaitu $\mathrm{P}<0,05$, kemudian dilanjutkan dengan uji Tukey HSD dimana taraf kepercayaan 95\%. Kesimpulan hasil statistika bahwa terdapat perbedaan yang signifikan antara kontrol negatif dengan formula gel antiseptik dengan kombinasi ekstrak daun kemangi dan ekstrak kulit jeruk purut, sehingga formula ini mempunyai efektifitas sebagai antiseptik. Variasi konsentrasi yang paling efektif sebagai hand sanitizer adalah konsentrasi ekstrak daun kemangi $75 \%$ dan konsentrasi ekstrak kulit jeruk purut $25 \%$. 
Kata Kunci : Daya Antiseptik, Daun Kemangi-Kulit Jeruk Purut, Gel Antiseptik (Hand Sanitizer)

\section{PENDAHULUAN}

Adanya

kecenderungan

masyarakat back to nature maka membuat masyarakat memilih produk yang dari bahan alami karena lebih aman dan memiliki efek samping lebih kecil dibandingkan produk dari bahan kimia. Sedangkan daun kemangi terbukti mempunyai aktivitas sebagai anti bakteri (Maryati dkk.,2007). Oleh karena itu, dalam penelitian ini digunakan kombinasi ekstrak daun kemangi dan ekstrak kulit jeruk purut sebagai anti bakteri dengan diformulasi dalam bentuk hand sanitizer. Penggunaan hand sanitizer dengan cara diteteskan pada telapak tangan dan kemudian diratakan di permukaan tangan dengan tujuan untuk menjaga tubuh terhindar dari penyakit khususnya infeksi yang disebabkan oleh mikroorganisme (Melisa S.,2013). Gel merupakan salah satu bentuk sediaan yang cukup digemari sebagai hand sanitizer. Bahan pembentuk gel yang digunakan pada penelitian ini adalah carbomer dengan nama dagang carbopol. Carbopol mempunyai keuntungan dibanding bahan pembentuk gel yang lain yaitu mempunyai sifat yang mudah didispersikan oleh air dan dengan konsentrasi yang kecil 0,05-2\% kekentalannya cukup sebagai basis gel.

Penelitian ini bermanfaat untuk pengembangan formulasi sediaan yang berbahan alam dalam rangka menjaga tubuh hidup higienis serta menghindari penyakit yang disebabkan oleh mikroorganisme. Dalam kehidupan masyarakat, sediaan ini sangat menguntungkan karena praktis dibawa kemana-mana karena kesadaran masyarakat dengan gaya hidup menjaga kebersihan sebelum dan sesudah makan. Oleh karena itu, sediaan hand sanitizer bermanfaat dalam kehidupan masyarakat maupun ilmu pengetahuan.

Efektivitas daya antiseptik hand sanitizer kombinasi ekstrak daun kemangi dan ekstrak kulit jeruk purut dilakukan dengan perbandingan variasi konsentrasi 25\%:75\%, 50\%:50\% dan 75\%:25\%. Selanjutnya daya antiseptik dari sediaan gel kombinasi ekstrak daun kemangi dan ekstrak kulit jeruk dibandingkan dengan daya antiseptik sediaan gel antiseptik tangan dengan bahan aktif etanol. Etanol memiliki sifat antibakteri (membunuh atau memperlambat) pertumbuhan bakteri.

Pengujian daya antiseptik dilakukan dengan metode Replika. Penelitian ini bertujuan untuk mengetahui apakah sediaan gel yang mengandung kombinasi ekstrak daun kemangi dan ekstrak kulit jeruk purut mempunyai daya antiseptik serta membandingkan daya antiseptik antara sediaan gel kombinasi ekstrak daun kemangi dan ekstrak kulit jeruk purut dengan sediaan gel antiseptik berbahan aktif etanol.

\section{METODE PENELITIAN \\ Rancangan Penelitian}

Jenis penelitian yang akan dilakukan adalah eksperimental dengan Post Test Control Group Design

\section{Alat dan Bahan Penelitian}

1. Bahan dan alat untuk ektraksi daun kemangi dan kulit jeruk purut

a. Bahan : serbuk simplisia daun kemangi, aquadest, 
etanol, serbuk simplisia kulit jeruk purut

b. Alat : panci infusa, neraca analitik,kompor listrik, beker glass, gelas ukur, batang pengaduk, cawan porselen, evaporator, waterbath, ayakan, oven..

2. Bahan dan alat untuk formulasi gel antiseptik kombinasi ekstrak daun kemangi dan ekstrak kulit jeruk purut

a. Bahan : ekstrak daun kemangi, ekstrak kulit jeruk purut, carbopol, $\mathrm{NaOH}$, gliserin, metil paraben, aquadest.

b. Alat : mortir dan stemper, wadah gel, timbangan analitik, hot plate, batang pengaduk, baskom kecil.

3. Bahan dan alat untuk uji fisik sediaan gel dengan bahan aktif kombinasi ekstrak daun kemangi dan ekstrak kulit jeruk purut

a. Uji organoleptik

Sediaan gel dengan bahan aktif kombinasi ekstrak daun kemangi dan ekstrak kulit jeruk purut.

b. Uji homogenitas

Sediaan gel dengan bahan aktif ekstrak kombinasi ekstrak daun kemangi dan ekstrak kulit jeruk purut, kaca transparan, batang pengaduk.

c. Uji pH

Sediaan gel dengan bahan aktif kombinasi ekstrak daun kemangi dan ekstrak kulit jeruk purut, $\mathrm{pH}$ meter.

d. Uji viskositas
Sediaan gel dengan bahan aktif kombinasi ekstrak daun kemangi dan ekstrak kulit jeruk purut, viskometer.

4. Bahan dan alat untuk uji antiseptik sediaan gel dengan bahan aktif kombinasi ekstrak daun kemangi dan ekstrak kulit jeruk purut

a. Bahan : Sediaan gel dengan bahan aktif ekstrak kulit batang kayu manis dan herba pegagan, gel sebagai kontrol positif, gel sebagai kontrol negatif, media NA (Nutrien Agar), phosphat buffer saline (PBS), aquadest.

b. Alat : inkubator, cawan petri (petridisk), tabung reaksi, pipet, label, vortex, kertas aluminium foil

\section{Tahapan Penelitian}

a. Ekstraksi daun kemangi

Daun kemangi segar dilakukan pengeringan hingga diperoleh simplisia daun kemangi dengan bobot tertentu yang selanjutnya akan dilakukan tahap ekstraksi. Ekstraksi simplisia daun kemangi dengan metode infundasi dimana sebanyak bobot tertentu simplisia (50 gram) kemudian ditambah aquadest $2000 \mathrm{ml}$ di atas penangas air selama 15 menit pada suhu $90^{\circ} \mathrm{C}$. Ekstrak disaring dengan kertas saring sampai didapat ekstrak air yang jernih. Ekstrak yang diperoleh di kumpulkan dan dipekatkan pada evaporator dan diuapkan di waterbath hingga memperoleh ekstrak kental.

b. Ekstraksi kulit jeruk purut 
Kulit jeruk purut dipotongpotong, kulit jeruk purut basah sebanyak 2000 gram dilakukan penyarian dengan metode maserasi dengan pelarut etanol $96 \%$ untuk mengambil zat aktif minyak atsiri. Serbuk simplisia yang dibuat dari pengeringan kulit jeruk purut, di ayak menggunakan ayakan 65 mesh, ditimbang sebanyak 199,17 gram dilarutkan dalam etanol $96 \%$ sebanyak $2.000 \mathrm{ml}$, kemudian ditutup dan dibiarkan selama 5 hari dan dilakukan pengadukan setiap harinya. Selanjutnya di saring, ampas di remaserasi selama 1 hari supaya penarikan ekstraksi lebih sempurna. Ekstrak yang diperoleh di kumpulkan dan dipekatkan pada evaporator dan diuapkan di waterbath hingga memperoleh ekstrak kental.

c. Formulasi sediaan gel antiseptik (handsanitizer) dengan bahan aktif kombinasi ekstrak daun kemangi dan ekstrak kulit jeruk purut

d. Pembuatan sediaan gel antiseptik (handsanitizer)

e. Evaluasi sediaan gel antiseptik (handsanitizer) kombinasi ekstrak daun kemangi dan ekstrak kulit jeruk

f. Uji daya antiseptik gel

\section{Analisis Hasil}

Dalam penelitian ini untuk mengetahui uji aktivitas antiseptik gel kombinasi ekstrak daun kemangi dan ekstrak kulit jeruk purut menggunakan uji Anova satu arah, dengan taraf signifikansi ( $\alpha$ $=0,05$ ). Jika terdapat perbedaan dilanjutkan uji Tukey HSD dengan taraf kepercayaan 95\% untuk mengetahui perbedaan antara kelompok perlakuan satu dengan yang lainnya.

\section{HASIL PENELITIAN}

Formula sediaan gel antiseptik (handsanitizer) kombinasi ekstrak daun kemangi dan ekstrak kulit jeruk perlu dilakukan evaluasi sediaan untuk mengetahui kualitas fisik sediaan atau formula yang dihasilkan.

\section{Tabel 1}

\section{Hasil pengamatan organoleptis sediaan} gel antiseptik (hand sanitizer)

\begin{tabular}{llll}
\hline $\begin{array}{l}\text { Kelompok } \\
\text { Perlakuan }\end{array}$ & Bentuk & Warna & Bau \\
\hline $\begin{array}{l}\text { Kontrol positif } \\
\text { Kontrol negatif }\end{array}$ & Gel & Jernih & $\begin{array}{l}\text { Alkohol } \\
\text { Tidak } \\
\text { berbau } \\
\text { Plkohol }\end{array}$ \\
$\begin{array}{l}\text { Formula I (ekstrak } \\
\text { daun kemangi 75\%: } \\
\text { ekstrak kulit jeruk }\end{array}$ & Gel & Coklat tua & Alkohol \\
$\begin{array}{l}\text { purut 25\%) } \\
\text { Formula II (ekstrak } \\
\text { daun kemangi 50\%: } \\
\text { ekstrak kulit jeruk } \\
\text { purut 50\%) }\end{array}$ & Gel & $\begin{array}{l}\text { Coklat } \\
\text { sedang }\end{array}$ & Armula III (ekstrak \\
$\begin{array}{l}\text { faun kemangi 25\%: } \\
\text { ekstrak kulit jeruk } \\
\text { purut 75\%) }\end{array}$ & Gel & $\begin{array}{l}\text { Coklat } \\
\text { muda }\end{array}$ & Alkohol \\
\hline & & & \\
\hline
\end{tabular}

Berdasarkan tabel di atas, bentuk formula berupa gel, warna formula coklat karena sesuai warna ekstrak yang digunakan dan berbau alkohol karena cairan penyari yang digunakan dalam proses ekstraksi kulit jeruk menggunakan etanol.

Tabel 2

Hasil pengamatan homogenitas sediaan gel antiseptik (hand sanitizer)

\begin{tabular}{ll} 
Kelompok Perlakuan & Homogenitas \\
\hline Kontrol positif & Homogen \\
Kontrol negatif & Homogen \\
$\begin{array}{l}\text { Formula I (ekstrak daun kemangi 75\%: } \\
\text { ekstrak kulit jeruk purut 25\%) }\end{array}$ & Homogen \\
$\begin{array}{l}\text { Formula II (ekstrak daun kemangi 50\%: } \\
\text { ekstrak kulit jeruk purut 50\%) }\end{array}$ & Homogen \\
$\begin{array}{l}\text { Formula III (ekstrak daun kemangi 25\%: } \\
\text { ekstrak kulit jeruk purut 75\%) }\end{array}$ & Homogen \\
\hline
\end{tabular}


Berdasarkan tabel di atas formula I, II dan III yang dihasilkan homogen dan tidak nampak ada butiran kasar dalam pengamatan.

\section{Tabel 3}

Hasil pengamatan pH sediaan gel antiseptik (hand sanitizer)

\begin{tabular}{lc}
\hline \multicolumn{1}{c}{ Kelompok Perlakuan } & $\mathrm{pH}$ \\
\hline Kontrol positif & 6 \\
Kontrol negatif & 5 \\
$\begin{array}{l}\text { Formula I (ekstrak daun kemangi 75\%: ekstrak kulit } \\
\text { jeruk purut 25\%) }\end{array}$ & 6 \\
$\begin{array}{l}\text { Formula II (ekstrak daun kemangi 50\%: ekstrak kulit } \\
\text { jeruk purut 50\%) }\end{array}$ & 5 \\
$\begin{array}{l}\text { Formula III (ekstrak daun kemangi 25\%: ekstrak kulit } \\
\text { jeruk purut 75\%) }\end{array}$ & 5 \\
\hline
\end{tabular}

Berdasarkan tabel di atas, $\mathrm{pH}$ yang dihasilkan pada formula I, II dan III sesuai dengan $\mathrm{pH}$ kulit yaitu pada interval 4-6,5. Formula I dimana kombinasi ekstrak daun kemangi $75 \%$ dan ekstrak kulit jeruk purut $25 \%$ mempunyai $\mathrm{pH}$ yang sama dengan $\mathrm{pH}$ kontrol positif yaitu $\mathrm{pH} 6$ dan tingkat keasamannya lebih rendah daripada formula yang lainnya.

\begin{tabular}{lc}
\multicolumn{1}{c}{$\begin{array}{c}\text { Tabel } 4 \\
\text { Hasil viskositas sediaan gel antiseptik } \\
\text { (hand sanitizer) }\end{array}$} \\
\hline \multicolumn{1}{c}{ Kelompok Perlakuan } & $\begin{array}{c}\text { Viskositas } \\
\text { (cps) }\end{array}$ \\
\hline $\begin{array}{l}\text { Kontrol negatif } \\
\text { Formula I (ekstrak daun kemangi 75\%: }\end{array}$ & 4100 \\
ekstrak kulit jeruk purut 25\%) & 4400 \\
$\begin{array}{l}\text { Formula II (ekstrak daun kemangi 50\%: } \\
\text { ekstrak kulit jeruk purut 50\%) }\end{array}$ & 4550 \\
$\begin{array}{l}\text { Formula III (ekstrak daun kemangi 25\%: } \\
\text { ekstrak kulit jeruk purut 75\%) }\end{array}$ & 4600 \\
\hline
\end{tabular}

Berdasarkan tabel di atas, dapat disimpulkan bahwa semakin tinggi konsentrasi ekstrak kulit jeruk purut dan semakin rendah konsentrasi ekstrak daun kemangi maka viskositas yang dihasilkan semakin kental. Hal ini dipengaruhi perbedaan cairan penyari dalam proses ekstraksi dimana untuk mengekstraksi kulit jeruk purut menggunakan pelarut alkohol, sedangkan untuk mengekstraksi daun kemangi menggunakan pelarut aquadest. Menurut Martin (2013), alkohol mempunyai viskositas yang lebih tinggi daripada air pada suhu $20^{\circ} \mathrm{C}$ dan air mempunyai viskositas paling rendah dibanding cairan umum lainnya yang digunakan di bidang farmasi. Oleh karena itu, nilai viskositas pada penelitian ini sesuai berdasarkan cairan pelarut pada proses ekstraksi.

\section{PEMBAHASAN}

Hasil uji daya antiseptik sediaan gel terhadap media nutrient agar dengan mengamati jumlah koloni bakteri yang terdapat dalam media tersebut setelah diinkubasi pada suhu $37^{\circ} \mathrm{C}$ selama 24 jam.

\section{Tabel 5}

\section{Hasil uji Tukey HSD kelompok} perlakuan terhadap jumlah koloni

\begin{tabular}{lcc}
\hline \multicolumn{1}{c}{ Kelompok } & \multicolumn{2}{c}{ Jumlah Koloni } \\
Perlakuan & Signifikansi & Keterangan \\
\hline $\begin{array}{l}\text { Kontrol (-) } \\
\text { kontrol (+) } \\
\text { Kontrol (-) }\end{array}$ & 0,000 & BB \\
formula I & 0,000 & BB \\
$\begin{array}{l}\text { Kontrol (-) } \\
\text { formula II } \\
\text { Kontrol (-) }\end{array}$ & 0,000 & BB \\
formula III \\
$\begin{array}{l}\text { Kontrol (+) } \\
\text { formula I }\end{array}$ & 0,000 & BB \\
$\begin{array}{l}\text { Kontrol (+) } \\
\text { formula II } \\
\text { Kontrol (+) } \\
\text { formula III }\end{array}$ & 0,359 & BTB \\
$\begin{array}{l}\text { Formula I } \\
\text { formula II } \\
\text { Formula I - } \\
\text { formula III }\end{array}$ & 0,055 & BTB \\
$\begin{array}{l}\text { Formula II - } \\
\text { formula III }\end{array}$ & 0,008 & BTB \\
\hline
\end{tabular}

Berdasarkan hasil uji Tukey HSD di atas maka dapat disimpulkan bahwa kelompok kontrol positif terdapat perbedaan yang signifikan dengan kelompok kontrol negatif. Hal ini berarti bahwa sediaan paten " $\mathrm{X}$ " gel antiseptik sebagai kontrol positif benar-benar mempunyai daya antiseptik. Formula I, formula II dan formula III berbeda signifikan kontrol negatif dan berbeda tidak signifikan dengan kontrol positif artinya bahwa formula I, II dan III 
mampu mempunyai daya antiseptik. Tetapi formula III mempunyai nilai siginifikansi paling besar yaitu 0,359 dibandingkan formula I dan II terhadap kontrol positif, artinya formula III mempunyai perbedaan yang tidak signifikan paling besar terhadap kontrol positif sehingga mempunyai daya antiseptik paling efektif dibanding formula I dan II. Jadi, sediaan gel antiseptik (hand sanitizer) dengan kombinasi ekstrak daun kemangi dengan konsentrasi $75 \%$ dan ekstrak kulit jeruk purut dengan konsentrasi $25 \%$ mempunyai daya antiseptik sebagai sediaan hand sanitizer yang paling efektif dibanding formula lainnya.

\section{KESIMPULAN DAN SARAN}

Sediaan gel antiseptik (hand sanitizer) kombinasi ekstrak daun kemangi dan ekstrak kulit jeruk purut mempunyai daya antiseptik.

Konsentrasi efektif kombinasi ekstrak daun kemangi dan ekstrak kulit jeruk purut formulasi gel sebagai daya antiseptik adalah kombinasi konsentrasi ekstrak daun kemangi $75 \%$ dan konsentrasi ekstrak kulit jeruk purut $25 \%$

Daya antiseptik sediaan gel antiseptik (hand sanitizer) kombinasi ekstrak daun kemangi dan ekstrak kulit jeruk purut berbeda tidak signifikan dengan kontrol positif produk paten hand sanitizer " $X$ " berbahan aktif etanol

\section{DAFTAR RUJUKAN}

Martin, A., Swabrick, J., dan Cammarata,A. 1993. Farmasi Fisik. UI Press. Jakarta

Maryati, Fauzia, R. S., danRahayu, T., 2007, Uji Aktivitas Antibakteri Minyak Atsiri Daun Kemangi (Ocimum basilicum L.)
terhadapStaphylococcus aureus dan Escherichia coli, Jurnal Penelitian Sains \& Teknologi, 8(1), 30-38.

Melisa S., 2013, Formulasi Sediaan Gel Hand Sanitizer dengan Bahan Aktif Triklosan $0,5 \%$ dan $1 \%$, Jurnal Ilmiah Mahasiswa Universitas Surabaya, Vol. 2 No.1 Naibaho,O.H., Yamlean,P. dan Weny Wiyono, 2013, Pengaruh Basis Salep terhadap Formulasi Sediaan Salep Ekstrak Daun Kemangi ( Ocimum Sanctuml.) pada Kulit Punggung Kelinci yang Dibuat Infeksi Staphylococcus Aureus, Pharmacon Jurnal Ilmiah Farmasi, Manado, UNSRAT Vol 2 No 2

Kurniawan A.,dkk.,2008, Ekstraksi Minyak Kulit Jeruk dengan Metode Distilasi, Pengepresan dan Leaching, Widya Teknik, Vol.7, No.1

Panjaitan, E. N., Saragih, A., Purba, D.2012. Formulasi Gel Dari Ekstrak Rimpang Jahe Merah (Zingiber officinale Roscoe). Journal of Pharmaceutics and Pharmacology, 2012 Vol. 1 (1): 920

Sinaga, S.R., 2012, Uji Banding Efektivitas Perasan Jeruk Purut (Citrus hystrix Dc) dengan Zinc Pyrithione $1 \%$ terhadap Pertumbuhan Pityrosporum Ovale pada Penderita Berketombe, Karya Tulis Ilmiah, Fakultas Kedokteran Undip, Semarang 